\title{
Effect of long-term treatment with aromatase inhibitor on testicular function of adult male bonnet monkeys (M. radiata)
}

\author{
Gunapala Shetty, Hanumanthappa Krishnamurthy, \\ Hegganahalli N. Krishnamurthy,* Ajay S. Bhatnagar, $\dagger$ and Nuggehali R. Moudgal* \\ *Department of Molecular Reproduction Development and Genetics Indian Institute of Science, \\ Bangalore 560 012, India and †Ciba-Geigy Ltd., Basel, Switzerland
}

\begin{abstract}
The role/need for estrogen in regulating testicular function of adult male bonnet monkeys (M. radiata) has been investigated by dosing orally a group of five normal males $2.5 \mathrm{mgs}$ of CGP 47645, a long-acting nonsteroidal aromatase inhibitor (AI), once every 5 days for over 150 days. Such treatment resulted in a 10-fold increment in nocturnal serum testosterone (T) levels, which were sustained for 85 days of treatment, and a twofold increment in basal serum T levels was present throughout the 150 days of treatment. Analysis of ejaculated semen showed a marked reduction ( 90\%) in sperm counts in four out of five monkeys between Days 55-85 of treatment. During this period, the motility score also was markedly reduced from a normal score of 3-5 to 0-2. Flow cytometric analysis of testicular germ cells obtained from biopsy tissue taken on Days 63 and 120 indicated a marked reduction only in elongating/elongated spermatid population (compared to Day 0 values), suggesting inhibition in spermiogenic process. Epididymal sperm maturation also seemed effected as sperm chromatin, on flow cytometric analysis for decondensability following exposure to $5 \mathrm{mM}$ dithiotreitol, showed to be in a hypercondensed state. This study thus indicates that estrogen has an important role in providing normal testicular and sperm function in the primate. (Steroids 63:414-420,
\end{abstract} 1998) (C) 1998 by Elsevier Science Inc.

Keywords: estrogen; primate; spermatogenesis; testicular function

\section{Introduction}

The ability of estrogen, a well-defined female hormone, to act as a feedback regulator of gonadotropins in both the female and male mammal is well known. The physiological role of estrogen in regulating testicular function, however, appears ill understood, and this perhaps is due to relatively low amounts of estrogen produced by the male as compared to the female. Although earlier studies led to the assertion that estrogen is synthesized by Leydig cells in adults and by Sertoli cells in prepubertal males ${ }^{1-6}$ there are also reports indicating that the seminiferous epithelium of the adult

Present address of Dr. Gunapala Shetty: Department of Experimental Radiotherapy, The University of Texas, M.D. Anderson Cancer Center, Houston, Texas, USA.

Present address of Dr. H. Krishnamurthy: Institute for Reproductive Medicine, University of Muenster, Muenster, Germany.

Present address of Dr. A. Bhatnagar: Novartis Pharma AG, K-125.12.16, Klybeckstrasse 141, CH-4002 Basel, Switzerland.

Address reprint requests to Prof. N. R. Moudgal, Primate Research Laboratory, Department of Molecular Reproduction, Development and Genetics, Indian Institute of Science, Bangalore 560 012, India.

Received November 24, 1997; accepted February 24, 1998. animal is capable of estrogen synthesis. ${ }^{7}$ Germ cells ${ }^{8}$ as well as placental tissue ${ }^{9}$ are also known to exhibit P-450 aromatase activity. Some of the recent studies involving the blockade of estrogen action by follicle regulatory proteins in male rats and $\operatorname{logs}^{10-12}$ and insertional disruption of estrogen receptor genes in rodents ${ }^{13,14}$ have indicated that estrogen may be required for normal testicular function in the male. In addition, the presence of estrogen receptors in the epididymis ${ }^{15-17}$ suggests a positive role for estrogen in sperm maturation.

Blockade of estrogen synthesis by specific aromatase inhibitors (AIs) is one of the best ways of studying estrogen action in vivo. Treatment with AI has been shown to enhance luteinizing hormone (LH) and testosterone (T) secretion in the human male ${ }^{18,19}$ and cynomolgus monkeys, ${ }^{20} \mathrm{a}$ positive feedback effect of estrogen deprival. In the present study, in bonnet monkeys ( $M$. radiata) a new generation nonsteroidal aromatase inhibitor of high specific activity, CGP 47645 [a fluoridated analog of Letrozole (CGS 20267), a much more widely studied AI] has been used to investigate the effect of blocking estrogen synthesis on testicular testosterone as well as sperm production. The 
results of our study, we believe, provide a better understanding of the physiological role of estrogen in regulating fertility in the male primate.

\section{Experimental}

\section{Hormones and chemicals}

The ovine luteinizing hormone (oLH) used was a laboratory preparation, with $1 \mathrm{ng}$ of this material exhibiting an activity profile equivalent to $0.133 \mathrm{ng}$ NIH-hLH (AFP-4745B) in the radio receptor assay. Tritiated $\mathrm{T}(97 \mathrm{ci} / \mathrm{m} \mathrm{mol})$ was purchased from Amersham, UK. Aromatase inhibitor CGP47645 was donated by CIBA Geigy Ltd, Basel, Switzerland. Dithiotreitol (DTT), ethidium bromide (EB), RNase, and Nonidet P-40 were from Sigma, St Louis, MO, USA. Papain and Dulbecco's phosphate buffered saline (DPBS) were obtained from Himedia, Bombay, India.

\section{General methodology}

Five healthy adult male bonnet monkeys ages 8-12 years weighing 7-9 kg each screened for normal diurnal $\mathrm{T}$ rhythms and spermatogenesis (by DNA flow cytometry using testicular tissue obtained by needle biopsy as well as semenology) were used for the study. The general care and maintenance of monkeys under conditions of controlled photo period (12L:12D) has been described earlier. ${ }^{21}$ The present study was cleared by institutional ethical committee for use of non-human primates for biomedical research.

\section{Treatment}

A dose of $2.5 \mathrm{mg}$ of CGP 47645 dissolved in $2.5 \mathrm{~mL}$ of ethanol was given by oral route (by means of a dropper) once every 5 days. This dose of AI was arrived at by determining the estrogen synthesis inhibiting efficacy as well as the duration of the effect of a single dose of the drug in appropriate rat and female monkey test systems. ${ }^{22,23}$ Oral administration of $50 \mu \mathrm{g}$ of CGP 47645 to immature rats totally blocked the PMSG-induced increase in the uterine weight for a minimum of 6 days. A single oral administration of CGP $47645(2.5 \mathrm{mg})$ to female monkeys on Day 7 of the cycle prevented estrogen levels increasing from a basal of $<80$ $\mathrm{pg} / \mathrm{mL}$ for the following 6 days. Normally, estrogen levels between Days $8-9$ of the cycle range between $200-600 \mathrm{pg} / \mathrm{mL}$. In addition, the administration of a single oral dose of CGP 47645 (4 mg/ monkey) to adult male monkeys resulted in serum testosterone being elevated over the control values for the succeeding 12 days; maximal increment, however, was achieved by the sixth day of administration. ${ }^{23}$ On the basis of these observations and considering that the production of estrogen in the male compared to the female is low, it was assumed that oral administration of $2.5 \mathrm{mg}$ of CGP 47645 to adult males should be adequate to block the aromatase activity for a minimum of 5 days.

\section{Blood sampling and testosterone assay}

Blood samples were collected from unanesthetized monkeys by way of femoral vein/arterial puncture using sterile vacutainer tubes (Becton-Dickinson, New Jersey, USA) at 10.00 and $20.00 \mathrm{~h}$ of the day and represented a.m. and p.m. values. The sera was separated within $12 \mathrm{~h}$ and stored at $-20^{\circ} \mathrm{C}$ until analysis.

Testosterone was analyzed by a specific radioimmunoassay described in detail earlier ${ }^{24}$ using ether extracted serum samples. The sensitivity of the assay was $10 \mathrm{pg} / \mathrm{tube}$, and the inter and intra-assay coefficients of variation were $9.8 \%$ and $8.3 \%$, respectively. The aliquot of serum sample used for assay varied depend- ing upon whether $\mathrm{T}$ was being measured in a.m. or p.m. samples of control and AI-treated monkeys.

\section{Quantitation of testicular germ cells by DNA flow cytometry}

Testicular needle biopsy was performed under ketamine anaesthesia as described earlier. ${ }^{25}$ Preparation of single-cell suspension of testicular germ cells ${ }^{26,27}$ and the procedure adapted for pepsinization and DNA staining of ethanol fixed cells with ethidium bromide have been described earlier. ${ }^{27,28}$ The flow cytometric analysis of stained germ cells was carried out using a FACScan (BectonDickinson, San Jones, CA, USA) flow cytometer equipped with an argon ion laser. At least 10,000 cells per sample were acquired and analysed using the LYSIS II software program (BectonDickinson). The germ cell distribution pattern (using leukocytes as internal diploid marker) showed four distinct cell populations based on DNA content-spermatogonia (2C), the cells in synthetic phase and primary spermatocytes (4C), round spermatids (1C), and elongating/elongated spermatids (HC). It was, however, possible to apply electronic gating to differentiate between elongating (HC1) and elongated (HC2) spermatids. The germ cell transformation ratios were calculated from $\%$ cell populations.

Ejaculated sperm samples from treated and control animals were decondensed by treating with DTT, the chromatin exposed to ethidium bromide and flow cytometrically analysed as described earlier. ${ }^{29}$ The DTT treatment brought about reduction of free thiol groups in the protamine.

\section{Seminal parameters}

Semen samples collected at 10- to 15-day intervals by electroejaculation were analyzed for sperm count and motility according to the procedure described in the WHO manual 1992.30

\section{Statistical analysis}

All data are expressed as mean \pm SEM. Significance of differences between $\mathrm{T}$ levels, testicular germ cell percentages, and seminal parameters during pretreatment and treatment phase were analyzed by Student's $t$ test.

\section{Results}

Effect of CGP 47645 on serum $T$ profile of adult male monkeys

Oral administration of CGP 47645 at a dose of $2.5 \mathrm{mg}$ once in 5 days over a period of 85 days resulted in a significant and sustained increment (approximately 10-fold increase in the basal and 5-fold increase in nocturnal values) in serum $\mathrm{T}$ levels. However, the high levels of serum $\mathrm{T}$ could not be maintained beyond 85 days of treatment, the nocturnal high levels reaching normal values by Day 180 of continued treatment. The basal levels of $\mathrm{T}$ all the same continued to be significantly high $(p<0.05)$ for the entire period of 180 days (Figure 1).

\section{Effects of AI treatment on seminal parameters}

Sperm count of four out of five treated monkeys was markedly reduced between Days 55-85 of treatment. At time points beyond this, the reduction in the sperm count of individual animals was not significant at consecutive time points, although the average counts did not revert back to 


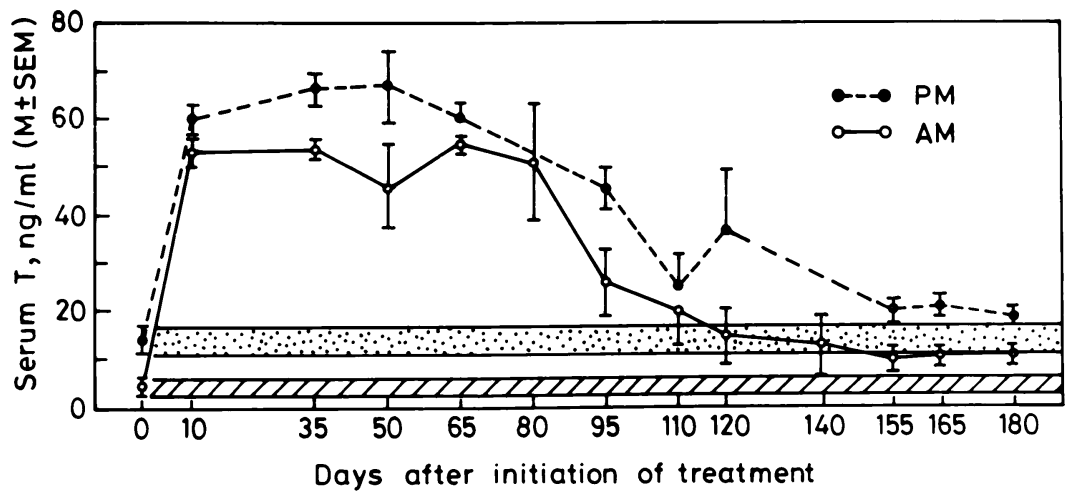

Figure 1 Serum testosterone profile in a group of five adult male bonnet monkeys chronically treated with a long-acting Al. The Al (CGP 47645) was administered orally at a dose of 2.5 $\mathrm{mg}$ once every 5 days. The range of normal serum testosterone values in a group of control monkeys ( $n=5)$ at $1000 \mathrm{~h}$ (a.m. values) and $2000 \mathrm{~h}$ (p.m. values) is represented by hatched and dotted areas, respectively. pretreatment value (Figure 2a). All five monkeys showed marked reduction in sperm motility, and the fertility index of these monkeys (sperm count $\times$ motility) was reduced from a Day 0 value of $870.2 \pm 180.5$ to $5.2 \pm 2.62(p<$ 0.0007 ) between Day 55 to 95 of treatment (Figure 2b). The variation in sperm counts of a group of control monkeys analysed over the same time period was within $10 \%$ of Day 0 value.

\section{Effect of blocking estrogen synthesis on spermatogenesis}

DNA flow cytometric analysis of germ cells processed from testicular biopsy tissue taken on Day 0, 63, and 120 of treatment showed that there was no significant change in the relative population of spermatogonia $(2 \mathrm{C})$, primary sper-

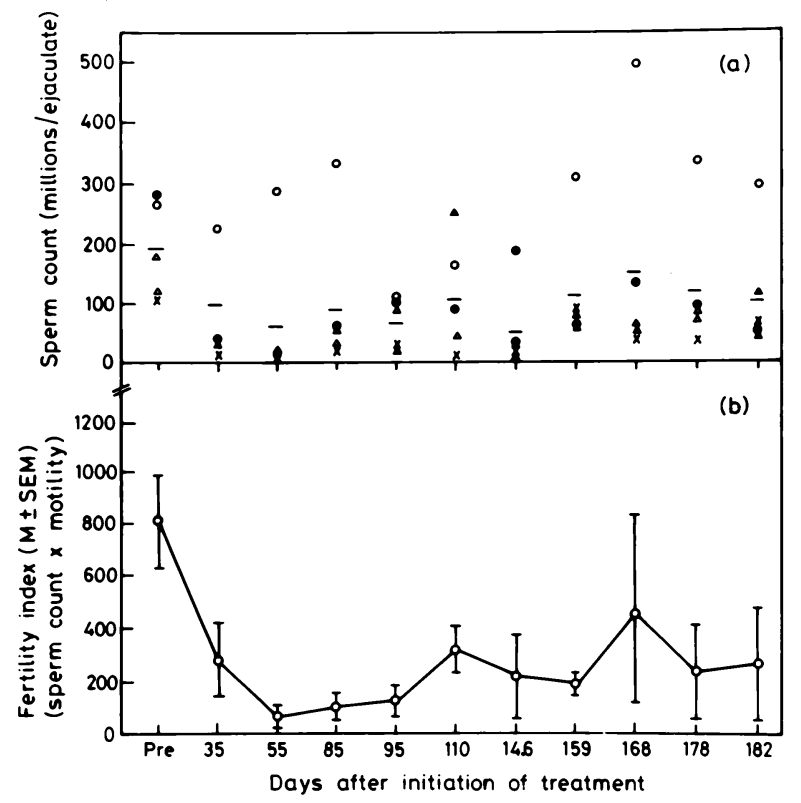

Figure 2 Sperm count and fertility index (a product of counts per million $\times$ motility score) of experimental monkeys during pretreatment and Al treatment period. A, the mean and individual sperm count values of five monkeys at different days of treatment. $B$, the fertility index (mean \pm SEM) at different times of the experiment $(n=5)$ is shown. For further details of experimental procedure, see text. matocytes (4C), and cells in synthetic phase (S-ph; Table 1). However, from the composite flowcytogram of the spermatid population obtained, it was evident that estrogen deprivation effected spermiogenesis (Figure 3). The transformation of round to elongating spermatids ( $\mathrm{HC1:1C}$ ) was inhibited by 47 and $53 \%$ by Days 63 and 120 of treatment, respectively. The elongated spermatid population (HC2) was reduced at Days 63 and 120 by 43 and $81 \%$, respectively $(p<0.001)$, and the transformation of round to elongated spermatid (HC2:1C) population at the above two time points appeared reduced by 15 and $88 \%$, respectively. The overall $\mathrm{HC} 1+\mathrm{HC} 2: 1 \mathrm{C}$ ratio changed from a normal of 1.11 (pretreatment value) to 0.78 by Days 63 and to 0.32 by Day 120 of treatment (Table 1), suggesting thereby that the lack of estrogen affects spermiogenesis specifically (transformation of round to elongating and elongated spermatids).

\section{In vivo response of AI-treated monkeys to oLH}

To better understand the functionality of Leydig cells in the AI-treated animals, the acute in vivo response of these monkeys to a bolus i.v. injection of oLH (1 mg) was determined. The results showed that the responsivity of the AI-treated monkeys $(n=2)$ as compared to the controls $(n=2)$ was twofold higher in terms of serum T production (Figure 4).

\section{Susceptibility of ejaculated sperms of control and AI-treated monkeys to DDT-induced decondensation}

Flow cytometric analysis showed that whereas sperm chromatin of control monkeys exhibit maximal decondensation when exposed to DTT concentrations of $5 \mathrm{mM}$ and higher, sperm of AI-treated monkeys showed significant reduction $(p<0.002)$ in decondensability even at $20 \mathrm{mM}$ DTT (Figure 5).

\section{Discussion}

It is well recognized that in the primate as in other mammals testicular testosterone production is under $\mathrm{LH}$ control. ${ }^{24}$ Testosterone has long been held as the primary feedback regulator of $\mathrm{LH}$ in mammals. AI is expected to block estrogen synthesis not only in major steroidproducing organs like the testis and adrenal but also in other tissues, such as the hypothalamo-pituitary-axis 
Estrogen and testicular function in primate: Shetty et al.

Table 1 Germ Cell Distribution Pattern in Monkeys Treated with Al, CGP 47645 on a Continuous Basis

\begin{tabular}{|c|c|c|c|c|c|c|c|c|}
\hline $\begin{array}{l}\text { Day of } \\
\text { treatment }\end{array}$ & $\begin{array}{c}\text { Spermatogonia } \\
2 \mathrm{C}\end{array}$ & $\begin{array}{l}\text { S-ph cells } \\
\text { in S-phase }\end{array}$ & $\begin{array}{c}\text { Primary } \\
\text { spermatocytes } \\
4 C\end{array}$ & $\begin{array}{c}\text { Round } \\
\text { spermatids } \\
\text { 1C }\end{array}$ & $\begin{array}{c}\text { Elongating } \\
\text { spermatids } \\
\text { HC1 }\end{array}$ & $\begin{array}{c}\text { Elongated } \\
\text { spermatids } \\
\text { HC2 }\end{array}$ & HC1:1C & $\mathrm{HC} 2: 1 \mathrm{C}$ \\
\hline 63 & $11.29 \pm 1.00$ & $1.90 \pm 0.30$ & $7.15 \pm 2.20$ & $21.31 \pm 0.30 *$ & $5.91 \pm 3.40 \dagger$ & $10.91 \pm 0.50^{*}$ & 0.27 & 0.51 \\
\hline 120 & $11.62 \pm 2.00$ & $2.78 \pm 0.40$ & $6.46 \pm 0.90$ & $52.57 \pm 0.90 *$ & $12.96 \pm 3.70$ & $3.66 \pm 2.10^{*}$ & 0.24 & 0.07 \\
\hline
\end{tabular}

Mean \pm SEM.

$n=5$.

Significantly different from Day 0 value: ${ }^{*} p<0.0001 ; \dagger p<0.05$.

placenta. Its use in the current study clearly establishes that it is estrogen rather than $\mathrm{T}$ that acts as the primary feedback regulator of gonadotropins (and as such $\mathrm{T}$ production) in the male primate. This is in agreement with earlier studies in primates (References 18-20 and 31$33)$. In rodents aromatization also is known to be essential for androgen-regulated feedback control of gonadotropins. ${ }^{34}$ Deprivation of estrogen by using a nonsteroidal AI (CGS 16949A), however, results in an increase in LH level in the female ${ }^{35}$ but not in the male rat (Reference 18, Shetty et al., unpublished data). The above observations also correlate with the recent observations in male mice $^{14}$ in which estrogen action was compromised by targeted disruption of estrogen receptor gene. The repeat

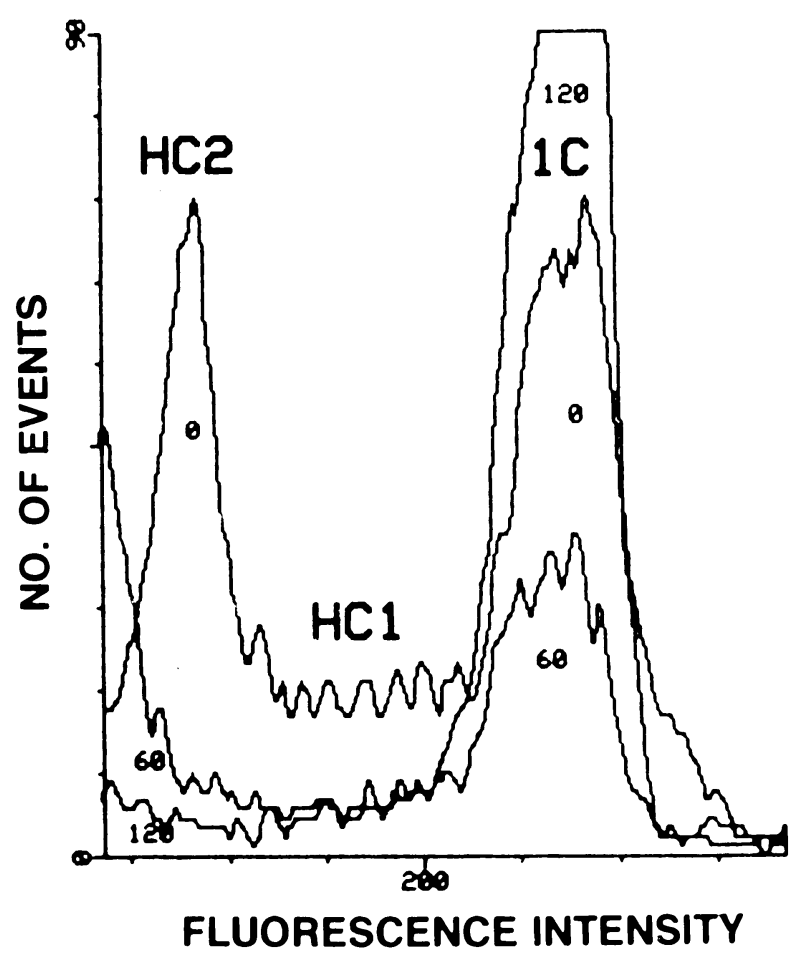

Figure 3 A typical flow cytogram of an aromatase inhibitortreated adult male monkey showing the effect on spermatid population. The numbers 0,60 , and 120 under each curve refer to days of treatment. The symbols $1 \mathrm{C}, \mathrm{HC}_{1}$, and $\mathrm{HC}_{2}$ refer to round, elongating, and elongated spermatid population, respectively. administration of the drug as carried out in the current monkey study could, by continuously inhibiting aromatase activity at the hypothalamo-pituitary axis, result in an increase in endogenous-circulating LH levels leading to a significant increase in serum $\mathrm{T}$. The inability of the drug to maintain nocturnal serum $\mathrm{T}$ levels at supraphysiological levels beyond Day 90, however, seems currently unexplainable. In an attempt to determine whether this is due to Leydig cells becoming desensitized to continuous stimulation by endogenous LH (perhaps as a consequence of lifting of feed back inhibition), monkeys were challenged on Day 166 of drug treatment with a bolus injection of oLH. The results showed that there was a good response to the bolus, in fact a response better than that provided by controls. This experiment all the same does not overrule completely the setting in of desensitization as we have observed earlier that the monkey testis could be desensitized to the action of a relatively lower level of endogenous LH administered several hours before a bolus injection of LH. These monkeys, although exhibiting a blockade of naturally occurring nocturnal testosterone surges, do respond to a bolus injection of $\mathrm{LH}$ by producing high $\mathrm{T}$ levels. ${ }^{36}$ Alternately it is possible that following continuous exposure to the drug the monkeys have developed newer metabolic clearance pathways for the drug resulting in its rapid clearance. The AI used here, CGP 47645, is known to have a relatively longer half-life than CGS 20267 and CGS 16949A.23 Treatment of dogs with the AIs CGP3249 and CGS 20267 has been suggested to cause hypertrophy and hyperplasia of testicular Leydig cells. ${ }^{37}$ Furthermore, estrogen produced by germ cells has been suggested to have a regulatory influence on androgen production through a negative feedback affect on Leydig cells. ${ }^{8}$

The current study has shown that the blockage of estrogen synthesis leads to compromise only in spermiogenesis and not spermatocytogenesis. Besides, the functional ability of sperm produced during Day 40-120 of treatment also seemed impaired. The flow cytometric analysis of germ cells indicated significant reduction in elongating/elongated population of spermatids between Days 60 to 120 of treatment, and this may be the reason for observing a marked reduction in sperm count during the early period of drug treatment. An additional parameter of defective spermiogenesis and sperm maturation was the observation that sperm motility was markedly 


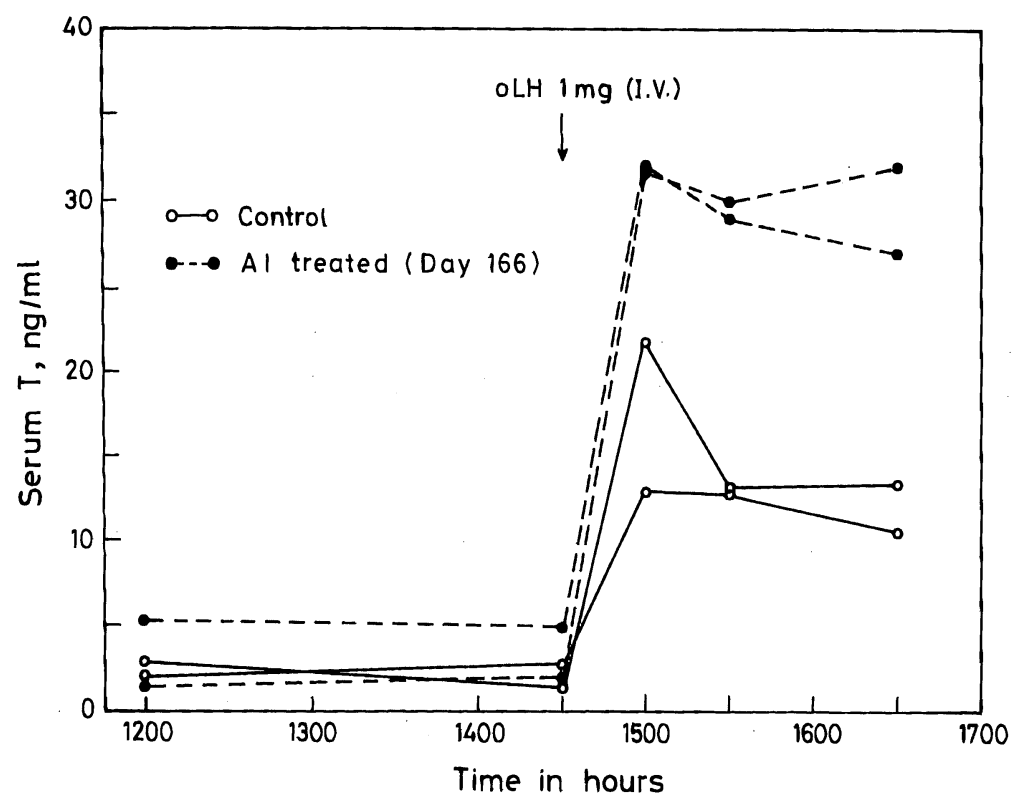

Figure 4 Testicular responsiveness of control -O- $(n=2)$ and Al treated -0- $(n=2)$ monkeys to a bolus injection of oLH (1 mg injected i.v.). Serum testosterone (T) levels before and following oLH injection are depicted.

reduced (a score of 0-2) in the treatment group compared to a score of 3-5 in the control group of monkeys, and this led to significant lowering of calculated fertility index (a product of motility score and sperm counts). Monkeys

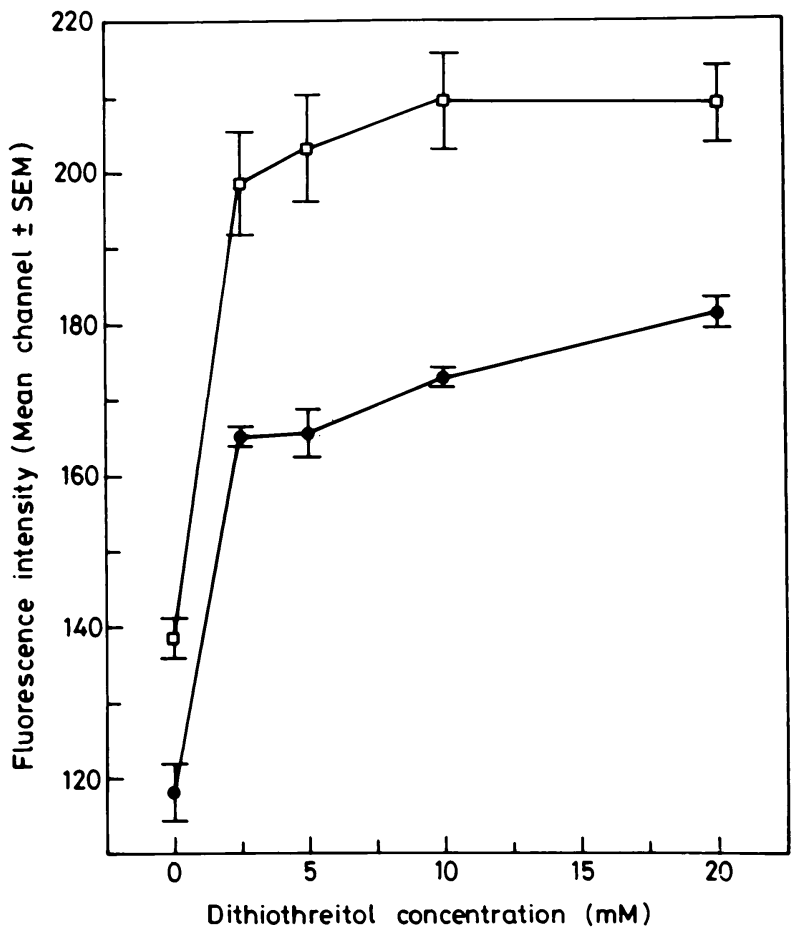

Figure 5 Effect of Al treatment on DTT-induced decondensation of sperm DNA. Ethidium bromide bound fluorescence (mean \pm SEM) of control $(\bigcirc ; n=5)$ and Al-treated $(0 ; n=4)$ sperms following exposure to different concentrations of DTT. exhibiting fertility index below 500 have been observed by us earlier to be infertile. ${ }^{38}$

The reduction in motility and concentration of sperms caused due to lack of estrogen may be due to more than one reason. Estrogen receptors are known to be present in sertoli cells ${ }^{39}$ as well as epididymis. ${ }^{17}$ In addition, the presence of $\mathrm{P} 450$ aromatase in germ cells (relatively more in spermatid than pachytene spermatocytes) of rodents has been reported. ${ }^{8}$ It has been hypothesized that estrogen produced by the germ cells may have a role in gene expression of spermatogenic or epithelial cell function in epididymis. ${ }^{8,14}$ This suggests that changes in sperm motility and concentration in AI-treated monkeys may be caused by the loss of estrogen action in Sertoli as well as germ cells. Improper or poor maturation of sperm during epididymal transit due to estrogen lack could be the cause of observed hypercondensation of sperms of AI-treated monkeys. This was of particular interest to us as we recently reported that vulnerability to DTT-induced decondensation of monkey sperms markedly increases following specific follicle-stimulating hormone deprivation. ${ }^{40,41}$ Interestingly, both hyper- and hypocondensation of ejaculated sperms have been correlated with infertility. ${ }^{42}$ In rodents, the blockage of estrogen action either by using aromatase inhibitors ${ }^{13,14}$ or by the disruption of estrogen receptors ${ }^{13,14}$ has been shown to impair fertility in general. Evidence indicating impairment in testicular function such as atrophy of interstitial cells, ${ }^{37}$ disruption of seminiferous epithelial function, ${ }^{11,14}$ reduced sperm function, ${ }^{14}$ and sexual activity ${ }^{14,43,44}$ following the blockage of estrogen function has also been reported. In conclusion, by observing that a specific lack of estrogen lack in adult male monkeys leads to defective spermiogenesis, which is accompanied by marked reduction in the quality and quantum of sperm produced, we tend to believe that 
estrogen could play a crucial role in regulating fertility in the male primate.

\section{Acknowledgments}

Financial support from the Rockefeller Foundation, New York, Department of Biotechnology, Government of India, New Delhi, Hormone Research Foundation, Bangalore (to G.S.), and Jawaharlal Nehru Center for Advanced Scientific Research, Bangalore (N. R. Moudgal is Sr. Associate of the Center) is gratefully acknowledged. The technical help of Dr. Ramachandra and Mr. Ramesh in monkey experimentation and Rosa J. Samuel in preparing the manuscript is appreciated.

\section{References}

1. Dorrington JM, Fritz B, Armstrong DT (1978). Control of testicular estrogen synthesis. Biol Reprod 18:55-64.

2. Pomerantx DK (1979). Effect of in vivo gonadotropin treatment on estrogen levels in the testis of the immature rats. Biol Reprod 21:1247-1255

3. Valladares LE, Payne AH (1979). Induction of testicular aromatization by luteinizing hormone in immature rats. Endocrinology 105:431-436.

4. Nozu K, Dafau ML, Catt KJ (1981). Estradiol receptor-mediated regulation of steroidogenesis in gonadotropin desensitized leydig cells. J Biol Chem 256:1915-1922.

5. Rommerts FFG, Brinkmann AO, Vander Molen HJ (1982). Development and cellular localization of rat testicular aromatase activity. J Reprod Fertil 65:281-288.

6. Carreau S, Papadopoulos V, Drosdowsky MA (1988). Stimulation of adult rat Leydig cell aromatase activity by a Sertoli cell factor. Endocrinology 122:1103-1109.

7. Pudney J, Canick JA, Clifford NM, Knapp JB, Callard GV (1985). Location of enzymes of androgen and estrogen biosynthesis in the testis of ground squirrel (Citellus teralis). Biol Reprod 33:971-980.

8. Nitta H, Bunick D, Hess RA, Janulisc, Newton SC, Millete CF, Osawa Y, Scizuta Y, Toda K, Bahr JM (1993). Germ cells of mouse testis express P450 aromatase. Endocrinology 132:1396-1401.

9. Inkster SE, Brodie AMH (1989). Immunocytochemical studies of aromatase in early and full-term human placental tissues. Biol Reprod 41:889-898.

10. Fugimori K, Montz FJ, Nakamura RM, Dizerega GS (1986). Inhibition of canine spermatogonial mitosis with follicle regulatory protein. Arch Androl 16:22-34.

11. Tsutsumi I, Fugimori F, Nakamura mathuu JP, Ono T, Dizerega GS (1987). Disruption of seminiferous epithelial function in the rat by ovarian protein. Biol Reprod 36:451-461.

12. Tsutsumi I, Toppari J, Campeau JD, Dizerega GS (1987). Reduction of fertility in the male rat by systemic treatment with follicle regulatory protein. Fertil Steril 47:659-695.

13. Lubalin DB, Moyer JS, Golding TS, Couse J, Korach KS, Smithies O (1993). Alteration of reproductive function but not prenatal sexual development after insertional disruption of the mouse estrogen receptor gene. Proc Natl Acad Sci USA 90:11162-11166.

14. Eddy EM, Washburn TF, Bunch DO, Goulding EH, Gladen BC, Lubahn DB, Korach KS (1996). Targeted disruption of the estrogen receptor gene in male mice causes alteration of spermatogenesis and infertility. Endocrinology 137:4796-4805.

15. Cooke PS, Young P, Hess RA, Cunha GR (1991). Estrogen receptor expression in developing epididymis efferent ductules and other male reproductive organs. Endocrinology 128:2874-2879.

16. Iguchi T, Uesugi Y, Sato T, Ohta Y, Tekasugi N (1991). Developmental pattern of estrogen receptor expression in male mouse genital organs. Mol Androl 3:109-119.

17. Ergiin S, Ungefroren H, Holstein AF, Davidoff MS (1997). Estrogen and progesterone receptors and estrogen receptor related antigen (ER-D5) in human epididymis. Mol Reprod Dev 47:448-45.

18. Bhatnagar AS, Muller Ph, Schenkel C, Trunet PF, Beh I, Schieweck
K (1992). Inhibition of estrogen biosynthesis and its consequences on gonadotrophin secretion in the male. J Steroid Biochem Mol Biol 41:437-443.

19. Trunet PF, Muller Ph, Bhatnagar AS, Dickes I, Monnet G, White G (1993). Open dose-finding study of a new potent and selective non-steroidal aromatase inhibitor CGS 20267 in healthy male subjects. J Clin Endocrinol Metab 77:319-323.

20. Resko JA, Connolly PB, Roselli CE, Abdelgadir SE, Choate JVA (1993). Differential effects of aromatase inhibition on luteinizing hormone secretion in intact and castrated male cynomolgus macaques. J Clin Endocrinol Metab 77:1529-1534.

21. Ravindranath N, Moudgal NR (1987). Use of tamoxifen, an antiestrogen in establishing a need for estrogen in early pregnancy in the bonnet monkeys (Macaca radiata). J Reprod Fertil 81:327-336.

22. Moudgal NR, Shetty G, Bhatnagar AS (1996). Use of a specific aromatase inhibitor for determining whether there is a role of oestrogen in follicle/oocyte maturation ovulation and preimplantation embryo development. J Reprod Fertil 50(Suppl.):69-81.

23. Shetty G, Krishnamurthy H, Krishnamurthy HN, Bhatnagar AS, Moudgal NR (1997). Effect of estrogen deprivation on the reproductive physiology of male and female primates. J Steroid Biochem Mol Biol 61:157-166.

24. Mukku VR, Murthy GSRC, Srinath BR, Ramasharma K, Kotagi SG, Moudgal NR (1981). Regulation of testosterone rhythmicity by gonadotropins in bonnet monkeys (Macaca radiata). Biol Reprod 24:814-819.

25. Medhamurthy R, Aravindan GR, Moudgal NR (1993). Hemiorchidectomy leads to dramatic and immediate alterations in pituitary follicle stimulating hormone secretion and the functional activity of the remaining testis in the adult male bonnet monkey (Macaca radiata). Biol Reprod 49:743-74.

26. Aravindan GR, Ravindranath N, Gopalkrishnan K, Moudgal NR (1990). DNA flow cytometric analysis of testicular germ cell populations of the bonnet monkey (Macaca radiata) as a function of sexual maturity. J Reprod Fertil 89:397-406.

27. Suresh R, Aravindan GR, Moudgal NR (1992). Quantitation of spermatogenesis by DNA flow cytometry: Comparative study among different species of mammals. J Biosci 17:413-419.

28. Suresh R, Moudgal NR (1995). A role of nocturnal serum testosterone surge in regulating spermatogenesis in the adult non-human primate. Endocrine 3:487-492.

29. Aravindan GR, Krishnamurthy H, Moudgal NR (1995). Rat epididymal sperm exhibit on dithiothreitol treatment in vitro quantifiable differences in patterns of light scatter uptake of 14C-iodoacetamide and binding of ethidium bromide to DNA. Ind J Exptal Biol 33: 899-910.

30. WHO (1987). WHO Laboratory Manual for the Examination of Human Semen and Semen Cervical Mucus Interaction. Cambridge University Press, Cambridge.

31. D'Agata R, Vicari E, Aliffi A, Gulizia S, Palumbo G (1981). Direct evidence in men for a role of endogenous estrogens in gonadotropin release. Acta Endocrinol (Copenh) 97:145-149.

32. Ellinwood WE, Hess DL, Roselli CE, Spies HG, Resko JA (1984). Inhibition of aromatization stimulates luteinizing hormone and testosterone secretion in adult male rhesus monkeys. J Clin Endocrinol Metab 59:1088-1096.

33. Smith EP, Boyd J, Frank GR, Takahashi H, Cohen RM, Specker B, Williams TC, Lubahn DB, Korach KS (1994). Estrogen resistance caused by a mutation in the estrogen-receptor gene in a man. $N$ Engl J Med 331:1056-1061.

34. Krey LC, MacLusky NJ, Davis PG, Lieberburf DI, Roy EJ (1982). Different intracellular mechanisms underlie testosterone's suppression of basal and stimulation of cyclic luteinizing hormone release in male and female rats. Endocrinology 110:2159-2167.

35. Bhatnagar AS, Batzl C, Hausler A, Nogues V (1993). The role of estrogen in the feedback regulation of follicle-stimulating hormone secretion in the female rat. J Steroid Biochem Mol Biol 47:161-166.

36. Dighe RR (1982). Studies gonadotropin: Studies on LH/hCG receptor interaction and regulation of $\mathrm{LH}$ receptor and steroidogenesis. Ph.D. thesis of Indian Institute of Science, Bangalore, India. pp. $1-200$. 
37. Walker VJ, Nogues V (1994). Changes induced by treatment with aromatase inhibitors in testicular Leydig cells of rats and dogs. Exp Toxic Pathol 46:211-213.

38. Moudgal NR, Sairam MR, Krishnamurthy HN, Surekha S, Krishnamurthy H, Khan H (1997). Immunization of male bonnet monkeys (M. Radiata) with a recombinant FSH receptor preparation affects testicular function and fertility. Endocrinology 138:3065-3068.

39. Lin T, Murono EP, Osterman J, Nankin HR (1981). Direct inhibition of rat Leydig cell function by tamoxifen. Metabolism 30:156-159.

40. Aravindan GR, Ravindranath N, Krishnamurthy H, Moudgal NR (1991). FSH deprivation in bonnet monkeys (M. radiata) affects ability of sperm DNA to bind acridine orange and undergo decondensation in vitro- a flow cytometric analysis. Proceedings of the 24th Annual Meeting of the Society for the Study of Reproduction, USA, Abst. No. 514, p. 181

41. Aravindan GR, Krishnamurthy H, Moudgal NR (1997). Enhanced susceptibility of follicle-stimulating hormone-deprived, infertile bonnet monkey (Macaca radiata) spermatozoa to dithiothreitol induced DNA decondensation in situ. $J$ Androl 18:688-697.

42. Engh E, Clausen OPF, Scholberg A, Tolletsrud A, Purvis K (1992) Relationship between sperm quality and chromatin condensation measured by sperm DNA fluorescence using flow cytometry. Int $J$ Androl 15:407-415.

43. Clancy AN, Zumpe D, Michael RP (1995). Intracerebral infusion of an aromatase inhibitor, sexual behaviour and brain estrogen receptor gene. Proc Natl Acad Sci USA 90:98-111. 